\title{
Computerized Semester Exams by Randomization Order of the Questions with Linear Congruential Generator Methods (Study Case: Agathos Vocational High School)
}

\author{
Fernaldi Makmur'), Benny Daniawan' ${ }^{2)}$, Andri Wijaya ${ }^{3)}$ \\ ${ }^{12)}$ Buddhi Dharma University \\ Jl. Imam Bonjol No. 41 Karawaci Ilir, Tangerang, Indonesia \\ 1)fernaldi63@gmail.com \\ ${ }^{2}$ b3n2y.miracle@gmail.com \\ 3)hahihuheho8899@gmail.com
}

\begin{tabular}{|c|c|}
\hline Article history: & Abstract \\
\hline $\begin{array}{l}\text { Received 3April 2019; } \\
\text { Revised April 2019; } \\
\text { Accepted April 2019; } \\
\text { Available online April } 2019\end{array}$ & $\begin{array}{l}\text { Taking advantage of computer technology in education will help the semester } \\
\text { exams in every school become simpler during the process of the exam and scoring, } \\
\text { Agathos Vocational High School use manual exam system. They have to print out }\end{array}$ \\
\hline $\begin{array}{l}\text { Keywords: } \\
\text { Computerized Exam } \\
\text { Linear Congruential Generator } \\
\text { Semester Exam } \\
\text { Student's Report } \\
\text { User Acceptance Testing }\end{array}$ & $\begin{array}{l}\text { the test, and unorganized archives when filing the student's results. To solving their } \\
\text { current problems designed a new system will organize the information } \\
\text { electronically in filling the student's grades and making a random order of questions } \\
\text { using Linear Congruential Generator (LCG) method. This computerized system } \\
\text { will help the teachers prepare the questions and answer, teacher only have three } \\
\text { days to input in database. Marking the answers and filling the grade are } \\
\text { automatically by system. With using LCG method, every student will get } \\
\text { randomized questions based on Student's ID Number, this will reduce the } \\
\text { possibility of cheating and the students will not be able to continue filling their } \\
\text { answers after the time is over. After implementation the system, it gives a benefit } \\
\text { to prepare for the exam from } 8 \text { days to } 1 \text { day. The system test results is } 64 \% \text { can be } \\
\text { accepted by the user. }\end{array}$ \\
\hline
\end{tabular}

\section{INTRODUCTION}

The rapid growth of era and also the information technology advances in Indonesia that are needed and used for daily needs have become common thing for humans. As sharing data for business, education and health needs as well as integrated data storage. Furthermore, by being connected to a computer network that is a system consisting of computers and network devices, that work together to achieve the same purpose so the computers can connect to each other and share data in one of the same server network[1]. Education is a process that takes place in life as an effort to balance conditions in oneself with external conditions. This balancing process is a form of survival that is carried out, so that oneself can follow every activity that takes place in life[2]. Developing technology can be implemented into the education sector, so school data can be integrated and minimize human error. The activity of teachers and school staff is faster in accessing and changing some school data as needed.

Vocational educationbuild 8 graduates competencies [3]. Beside that vocational education has three main benefits: (a) for students as self-improvement, increased opportunities for employment, increased opportunities for entrepreneurship, increased income, preparation of further education, self-preparation for society, nation, state, adaptation to change and environment; (b) for the world of industry can obtain high-quality workforce, ease the cost of business, help advance and develop the business; (c) for the society can improve people's welfare, increase national productivity, increase state income, and reduce unemployment. Seeing the benefits of advances in information technology so many educational institutions began to develop their systems, so that the system became integrated using network servers. As well as in the implementation of the National Examination conducted by computer-based by several schools.

Based on information from the Principal, Agathos Vocational School is one of the Vocational High Schools that has two specializations that is Accounting and Multimedia which in the implementation of semester exams still manually have to print semester exam question sheets and it take up for one week, students still continue the semester 
exams even though the exams time is up so the activity of the teacher is hindered, the possibility of students cheating on the semester exam, the teacher needs more time in correcting the answers, several day overtime work and irregular storage of student grades that slows down the teacher's work process.With the development of information technology, makes Agathos Vocational School wants to improve their system.So Agathos Vocational School no longer needs to prepare for semester exam equipment, students become time discipline, students can not cheat, teachers doesn't need to correct answers by manually because the value directly in database and stores student value data become organized and easily accessed by teachers who need it.To prevent students from cheating during the semester examination, the system formed uses the Linear Congruent Generator (LCG) as a method of randomizing semester exam questions and report card features that can process student academic grades such as: assignments and semester exams to be final grades so they can be used by homerooms to ease the printing of student report cards.

\section{STUdyOF LiteratURE}

\begin{tabular}{|c|c|c|c|c|c|c|c|}
\hline $\begin{array}{l}\mathrm{N} \\
\mathrm{o}\end{array}$ & Title & Abstract & Object & Methods & Results & Conclusion & Keyword \\
\hline 1 & $\begin{array}{l}\text { Modifikasi } \\
\text { Metode Linear } \\
\text { Congurential } \\
\text { Generator untuk } \\
\text { Optimalisasi } \\
\text { Hasil Acak }\end{array}$ & $\begin{array}{l}\text { Conventional } \\
\text { exam } \\
\text { implementation } \\
\text { is considered to } \\
\text { be less effective } \\
\text { and efficient } \\
\text { because it } \\
\text { requires large } \\
\text { costs and a long } \\
\text { time in its } \\
\text { implementation } \\
\text { so it needs to be } \\
\text { improved by } \\
\text { changing the } \\
\text { examination } \\
\text { system to } \\
\text { computerization } \\
\text {. In each test } \\
\text { execution, it is } \\
\text { necessary to pay } \\
\text { attention to } \\
\text { fraudulent } \\
\text { actions by } \\
\text { students in the } \\
\text { form of cheating } \\
\text { and cooperation } \\
\text { in exchanging } \\
\text { answers. This } \\
\text { study aims to } \\
\text { provide } \\
\text { different } \\
\text { random } \\
\text { questions to } \\
\text { each student } \\
\text { using the Linear } \\
\text { Congruential } \\
\text { Generator } \\
\text { (LCG) method. } \\
\text { However, the } \\
\text { use of the LCG } \\
\text { method still has } \\
\text { weaknesses } \\
\text { where the } \\
\text { results of } \\
\text { randomization } \\
\text { are easy to }\end{array}$ & $\begin{array}{l}\text { Conventiona } \\
\text { l exam }\end{array}$ & $\begin{array}{l}\text { Linear } \\
\text { Congruentia } \\
1 \text { Generator } \\
\text { dan Couple } \\
\text { Linear } \\
\text { Congruentia } \\
1 \text { Generator }\end{array}$ & $\begin{array}{l}\text { CLCG } \\
\text { produces } \\
\text { more patterns } \\
\text { because the } \\
\text { process } \\
\text { carried out } \\
\text { uses two } \\
\text { linear } \\
\text { equations and } \\
\text { the results } \\
\text { form two } \\
\text { vectors } \\
\text { namely row } \\
\text { vectors and } \\
\text { column } \\
\text { vectors. The } \\
\text { randomizatio } \\
\text { n pattern } \\
\text { system is } \\
\text { difficult to } \\
\text { predict. }\end{array}$ & $\begin{array}{l}\text { The } \\
\text { simulation } \\
\text { results show } \\
\text { that the } \\
\text { Couple } \\
\text { Linear } \\
\text { Congruential } \\
\text { Generator } \\
\text { method has a } \\
\text { more } \\
\text { complicated } \\
\text { randomizatio } \\
\text { n pattern than } \\
\text { the Linear } \\
\text { Congruential } \\
\text { Generator } \\
\text { method. The } \\
\text { randomizatio } \\
\text { n pattern is } \\
\text { influenced by } \\
\text { the value and } \\
\text { amount of the } \\
\text { combination } \\
\text { of values } \\
\text { given to the } \\
\text { variable. In } \\
\text { addition, the } \\
\text { more variable } \\
\text { values are, } \\
\text { the more } \\
\text { complicated } \\
\text { the } \\
\text { randomizatio } \\
\mathrm{n} \text { pattern } \\
\text { produced by } \\
\text { CLCG. }\end{array}$ & $\begin{array}{l}\text { LCG, CLCG, } \\
\text { Pattern, } \\
\text { Randomizatio } \\
\mathrm{n}\end{array}$ \\
\hline
\end{tabular}




\begin{tabular}{|c|c|c|c|c|c|c|c|}
\hline & & $\begin{array}{l}\text { guess, so the } \\
\text { need to optimize } \\
\text { randomization } \\
\text { is to use two } \\
\text { LCG and the } \\
\text { help of the } \\
\text { matrix which is } \\
\text { the Coupled } \\
\text { Linear } \\
\text { Congruential } \\
\text { Generator } \\
\text { (CLCG) } \\
\text { method. The } \\
\text { modified CLCG } \\
\text { method } \\
\text { produces better } \\
\text { randomization } \\
\text { and a more } \\
\text { complex pattern } \\
\text { compared to the } \\
\text { LCG method. }\end{array}$ & & & & & \\
\hline 2 & $\begin{array}{l}\text { Penerapan } \\
\text { Metode Linear } \\
\text { Congurent } \\
\text { Method (LCM) } \\
\text { Dalam } \\
\text { Perancangan } \\
\text { dan Pembuatan } \\
\text { Game Monopoli } \\
\text { Edukasi untuk } \\
\text { Tokoh } \\
\text { Pahlawan } \\
\text { Nasional }\end{array}$ & $\begin{array}{l}\text { The lack of } \\
\text { supporting } \\
\text { media in } \\
\text { introducing } \\
\text { National Hero } \\
\text { Figures made } \\
\text { people less } \\
\text { familiar with } \\
\text { their own Hero } \\
\text { Figures, for this } \\
\text { reason } \\
\text { appropriate } \\
\text { media was } \\
\text { needed in } \\
\text { introducing } \\
\text { National Hero } \\
\text { Figures, one of } \\
\text { which was } \\
\text { through the } \\
\text { Educational } \\
\text { Monopoly } \\
\text { Game that could } \\
\text { provide } \\
\text { information } \\
\text { about National } \\
\text { Heroes. The } \\
\text { Linear } \\
\text { Congruent } \\
\text { Method (LCM) } \\
\text { is used to } \\
\text { randomize } \\
\text { questions on } \\
\text { monopoly } \\
\text { games. Based } \\
\text { on the results of } \\
\text { testing, the } \\
\text { Linear } \\
\text { Congruent } \\
\text { Method (LCM) } \\
\text { randomization } \\
\text { method can be }\end{array}$ & $\begin{array}{l}\text { Monopoli } \\
\text { Game }\end{array}$ & $\begin{array}{l}\text { Linear } \\
\text { Congurent } \\
\text { Method }\end{array}$ & $\begin{array}{l}\text { The right } \\
\text { combination } \\
\text { of constants } \\
\text { will result in } \\
\text { randomizatio } \\
n \text { of truly } \\
\text { random } \\
\text { questions and } \\
\text { avoid the } \\
\text { occurrence of } \\
\text { repetition of } \\
\text { randomizatio } \\
n \text { because it } \\
\text { uses the LCM } \\
\text { method }\end{array}$ & $\begin{array}{l}\text { There is no } \\
\text { recurrence of } \\
\text { the same } \\
\text { randomizatio } \\
\mathrm{n} \text { when the } \\
\text { game is } \\
\text { played. }\end{array}$ & $\begin{array}{l}\text { Education } \\
\text { Games, LCG, } \\
\text { National } \\
\text { Heroes }\end{array}$ \\
\hline
\end{tabular}




\begin{tabular}{|c|c|c|c|c|c|c|c|}
\hline & & $\begin{array}{l}\text { implemented in } \\
\text { the Monopoly } \\
\text { Education game } \\
\text { for National } \\
\text { Hero Figures. In } \\
\text { this study there } \\
\text { was no } \\
\text { repetition of the } \\
\text { same question } \\
\text { when the } \\
\text { application was } \\
\text { reopened. }\end{array}$ & & & & & \\
\hline 3 & $\begin{array}{l}\text { Design and } \\
\text { Implementation } \\
\text { s of Linear } \\
\text { Congruential } \\
\text { Generator into } \\
\text { FPGA }\end{array}$ & $\begin{array}{l}\text { This paper } \\
\text { exposes circuit } \\
\text { design of } \\
\text { linear } \\
\text { congruential } \\
\text { generator } \\
\text { (LCG) and } \\
\text { implementatio } \\
\text { n in FPGA. } \\
\text { The circuit is } \\
\text { derived from } \\
\text { LCG algorithm } \\
\text { proposed by } \\
\text { Lehmer. } \\
\text { Wordlengths } \\
\text { reduction } \\
\text { technique has } \\
\text { been used to } \\
\text { simplify the } \\
\text { circuit. Several } \\
\text { nets } \\
\text { connection } \\
\text { among the } \\
\text { blocks of the } \\
\text { circuit are } \\
\text { ignored or } \\
\text { disconnected. } \\
\text { Simulation } \\
\text { either behavior } \\
\text { or timing have } \\
\text { been done } \\
\text { successfully. } \\
\text { Four best } \\
\text { Xilinx chips } \\
\text { are chosen to } \\
\text { gather } \\
\text { comparison } \\
\text { data of } \\
\text { maximum } \\
\text { speed and } \\
\text { area occupied. } \\
\text { Kintex } 7 \text { is the } \\
\text { fastest chip } \\
\text { among all it is } \\
\text { about } 309 \\
\text { MHz and } \\
\text { Spartan } 6 \text { is } \\
\text { slowest one } \\
\text { which is only } \\
73 \text { MHz. The }\end{array}$ & $\begin{array}{l}\text { Circuit } \\
\text { Design of } \\
\text { LCG }\end{array}$ & $\begin{array}{l}\text { Linear } \\
\text { Congurent } \\
\text { ial } \\
\text { Generator }\end{array}$ & $\begin{array}{l}\text { The } \\
\text { maximum } \\
\text { frequency of } \\
\text { the design } \\
\text { circuit is } 309 \\
\text { MHz. Kintex } \\
7 \text { is the best } \\
\text { chip that } \\
\text { applies the } \\
\text { LCG circuit } \\
\text { design }\end{array}$ & $\begin{array}{l}\text { The } \\
\text { maximum } \\
\text { frequency of } \\
\text { the design } \\
\text { circuit is } 309 \\
\text { MHz (Kintex } \\
7, \mathrm{~m}=255 \text { ), } \\
\text { and the } \\
\text { minimum } \\
\text { frequency is } \\
73 \mathrm{MHz} \\
\text { (Spartan 6, m } \\
=231-1 \text { ). } \\
\text { Kintex } 7 \text { is } \\
\text { the best chip } \\
\text { that applies } \\
\text { the LCG } \\
\text { design circuit. }\end{array}$ & $\begin{array}{l}\text { LCG, FPGA, } \\
\text { Xilinx, Word } \\
\text { Length } \\
\text { Reduction, } \\
\text { Kintex }\end{array}$ \\
\hline
\end{tabular}




\begin{tabular}{|l|l|l|l|l|l|l|}
\hline & $\begin{array}{l}\text { area occupied } \\
\text { is similar } \\
\text { among all of } \\
\text { the selected } \\
\text { chips. }\end{array}$ & & & & & \\
\hline
\end{tabular}

\section{FRAMEWORK}

The following is a description of the framework:

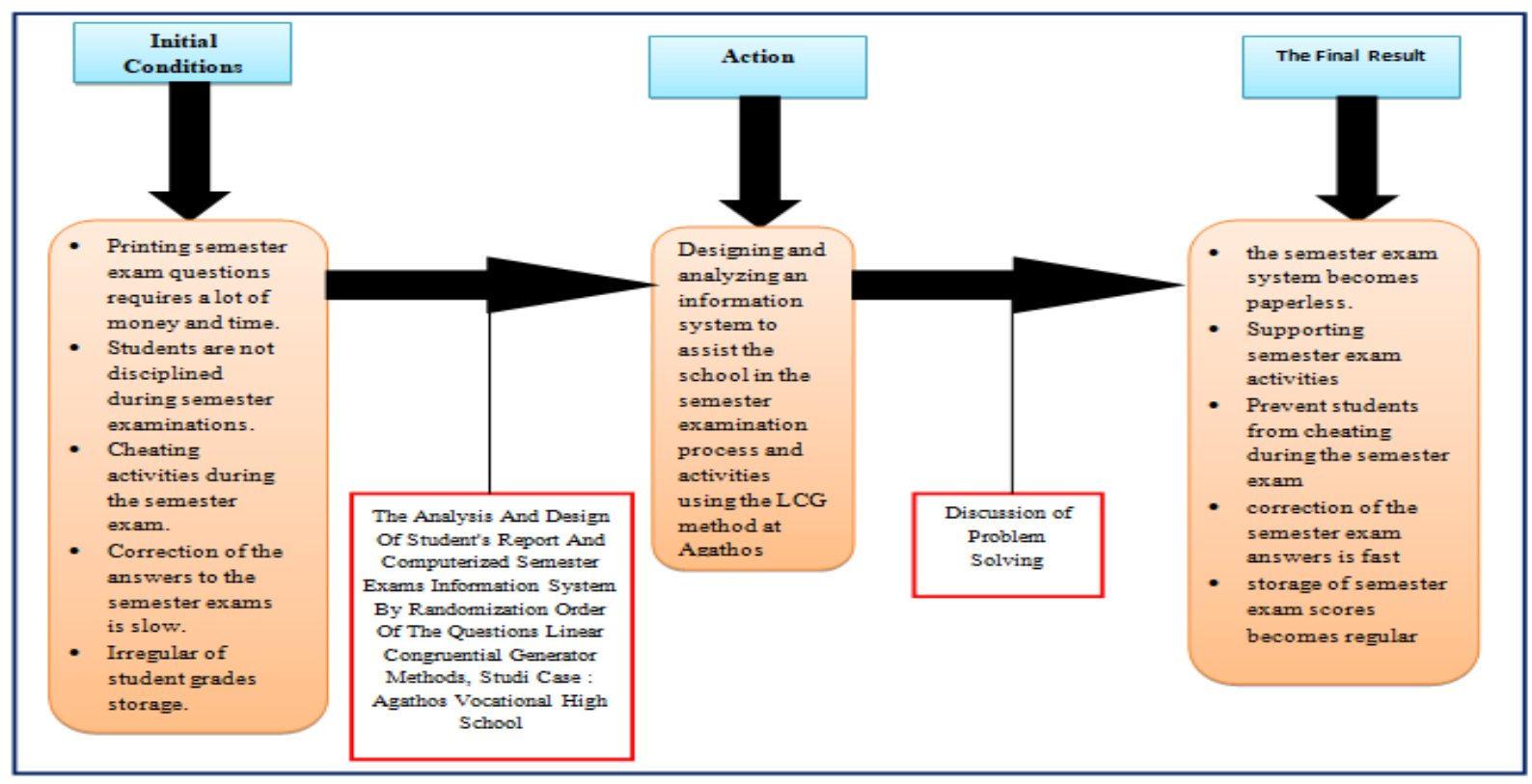

Fig.1 Computerized Semester Exams with LCG Method

In figure. 1 shows the problems exist in the current conditions in Agathos Vocational High School, by observing and interviewing for several days to the user, it can be concluded that Agathos requires a computerized system to solve the problems that have occurred. By using computerized exam and LCG method, it will provide better result.

\section{METHODS}

Linear Congruential Generator (LCG) Random numbers resulting from processing computer programs are pseudo random numbers, this is because the generation process uses arithmetic operations. Algorithms or methods have been often used to generate random numbers. Linear Congruential Generator (LCG) method is a method of generating random numbers that are often used in computer programs. LCG uses a linear model to generate random numbers defined by:

$\mathrm{Xn}=(\mathrm{aXn}-1)+\mathrm{b}$ mod $\mathrm{m}$
Where:
$\mathrm{Xn} \quad=$ the $\mathrm{n}^{\text {th }}$ of random number
$\mathrm{Xn}-1=$ previous random number
$\mathrm{a} \quad=$ multiplier
$\mathrm{b} \quad=$ increment


$\mathrm{m} \quad=$ modulus

$\mathrm{X} 0$ is the initial key to randomization of a sequence, also called seed.

The initial period of numbers that will be randomized from the Linear Congruential Generator (LCG) method is not greater than the modulus $(\mathrm{m})$, and some cases show that the randomization results does not exceed the modulus (m).This LCG method has the advantage at a speed where only a few bit operations are needed. This Linear Congruential Generator (LCG) method has its own characteristic, that is, there will be a repetition at several randomization times in a certain period if the modulus $(\mathrm{m})$ is greater than the number of numbers to be randomized. The repetition is one of the deficiencies that this method has. One of the characteristics of this method is that there is a repetition in a certain period of time or after randomization, to overcome the repetition, the determination of the LCG constants ( $\mathrm{a}, \mathrm{b}$ and $\mathrm{m}$ ) determines whether or not random numbers are obtained in the sense of obtaining random numbers as if there was no repetition by doing several tests[5].

\section{RESULTS}

The result of the study by using LCG method was implemented into Agathos Vocational School Systems as in figure below:

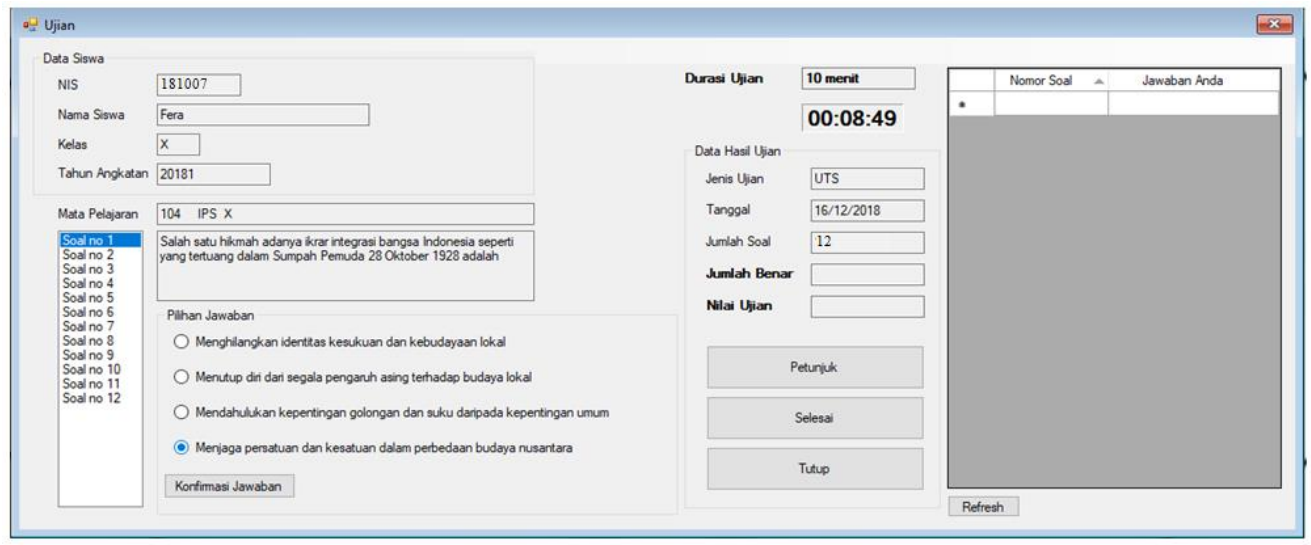

Fig. 2 Random question use Linear Congruental Method

In figure. 2 show the question which using Linear Congruential Method. Every student after Login by their Student's ID number will get random questions. The last three digits of the student id, will be entered into the LCG randomization method, as explained earlier above. That's automaticly shuffle the number of question on every computer which used by students for exam.

In this stage the method is explained thoroughly in the process of randomizing the sequence. With the example three digit last of Student's ID Number is 7 and the number of questions is 12.

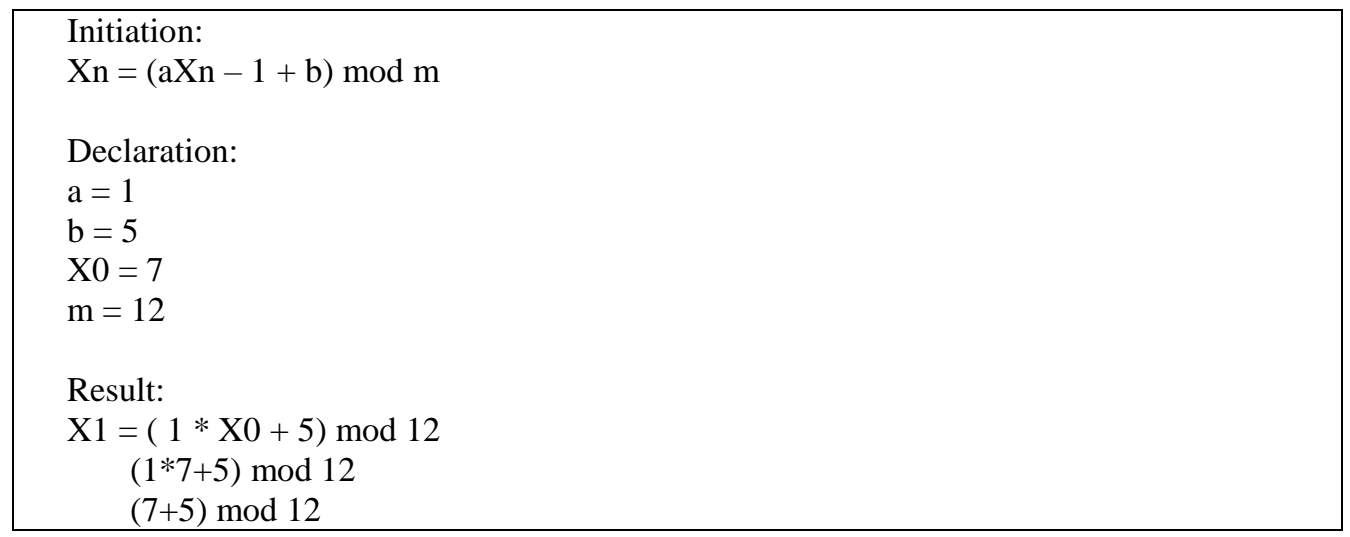




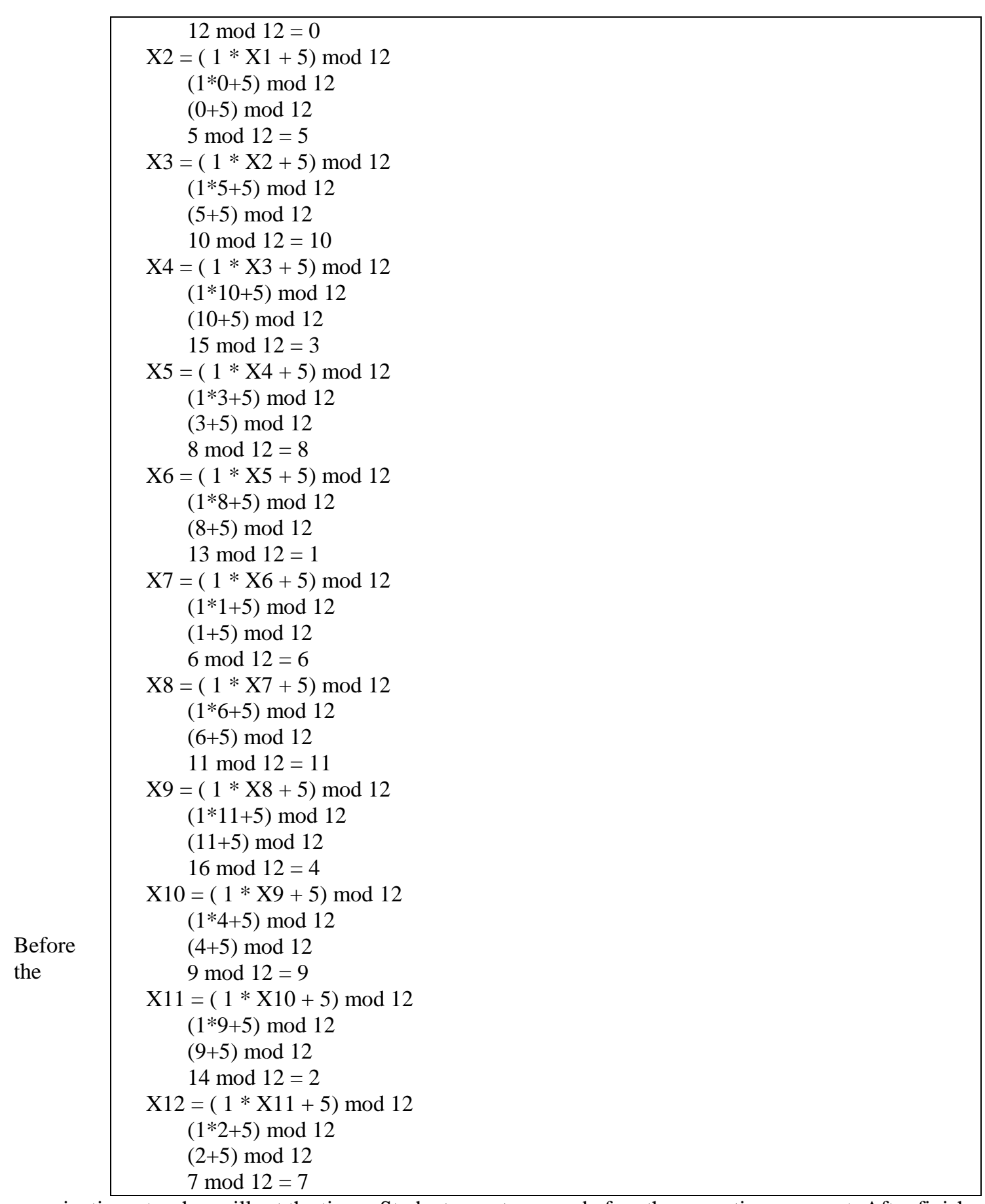

begin

examinations, teacher will set the timer. Students must answer before the exam time runs out. After finish system will calculated the grade, and show the result. 


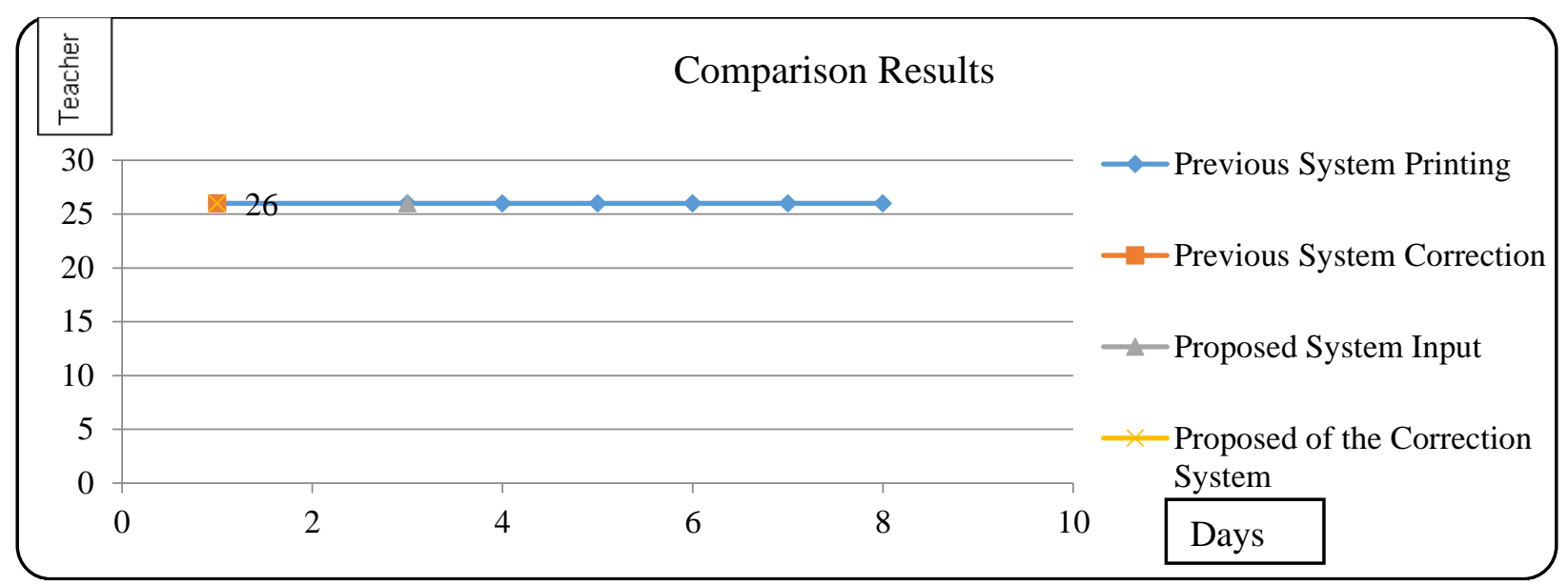

Fig. 3 Comparison of Result Charts

In figure. 3 show the comparison currently system need 8 days to prepare and print the question paper, and Plus one day to correction the result. After implemented the new system, it's only need three days to input the question in database, and one day for the exam along with correction of exam result.

Table I. Comparative Results

\begin{tabular}{|c|c|c|}
\hline No & Previous System & Proposed System \\
\hline 1 & $\begin{array}{l}\text { Printing takes } 8 \text { days and costs per question } \\
\text { Ex: } 150 / \text { question sheets, } 15 \text { subjects, } 67 \text { students, } \\
\quad 4 \text { sheets question/subjects } \\
\quad 150 \times 15=\mathrm{Rp} 2250 / \text { student; } \\
\quad \mathrm{Rp} 2400 \times 67=\mathrm{Rp} 150.750 \\
\text { Total expense each semester is : Rp } 150.750 \times 4 \\
=\text { Rp } 603.000\end{array}$ & The Input process done in 3 days and Paperless \\
\hline 2 & $\begin{array}{l}\text { Students still continue semester exams even } \\
\text { though the exams time is up }\end{array}$ & $\begin{array}{l}\text { Students fill the questions answer according the } \\
\text { set of duration }\end{array}$ \\
\hline 3 & Students have the possibility of cheating & $\begin{array}{l}\text { The order of the question is randomized based by } \\
\text { Student's ID Number with implementation of } \\
\text { Linear Congruential Generator method. So each } \\
\text { student will be get a different questions. }\end{array}$ \\
\hline 4 & $\begin{array}{l}\text { - } 8 \text { days for printing question sheets } \\
\text { - } 1 \text { day plus overtime work to correct semester } \\
\text { exam answer sheets }\end{array}$ & $\begin{array}{l}\text { - } 3 \text { days Inputted questions are stored in the } \\
\text { database } \\
\text { - The results of the semester exam are } \\
\text { immediately calculated }\end{array}$ \\
\hline 5 & Students grades are still physically stored & Student grades are stored in the database \\
\hline
\end{tabular}

\section{TESTING}

Black Box Testingis "The testing software in terms of functional specifications without testing the design and program code"[8].So the Black Box testing method focuses on the functional requirements of the software. System testing is done by observing the output of various inputs. If the system output is in accordance with the design for data variations, then the system is declared good. Black Box testing is not an alternative to white box testing, but is a 
complementary approach to finding other errors, besides using the white Box testing method. The result show below Table II.

Table II. Black Box Testing

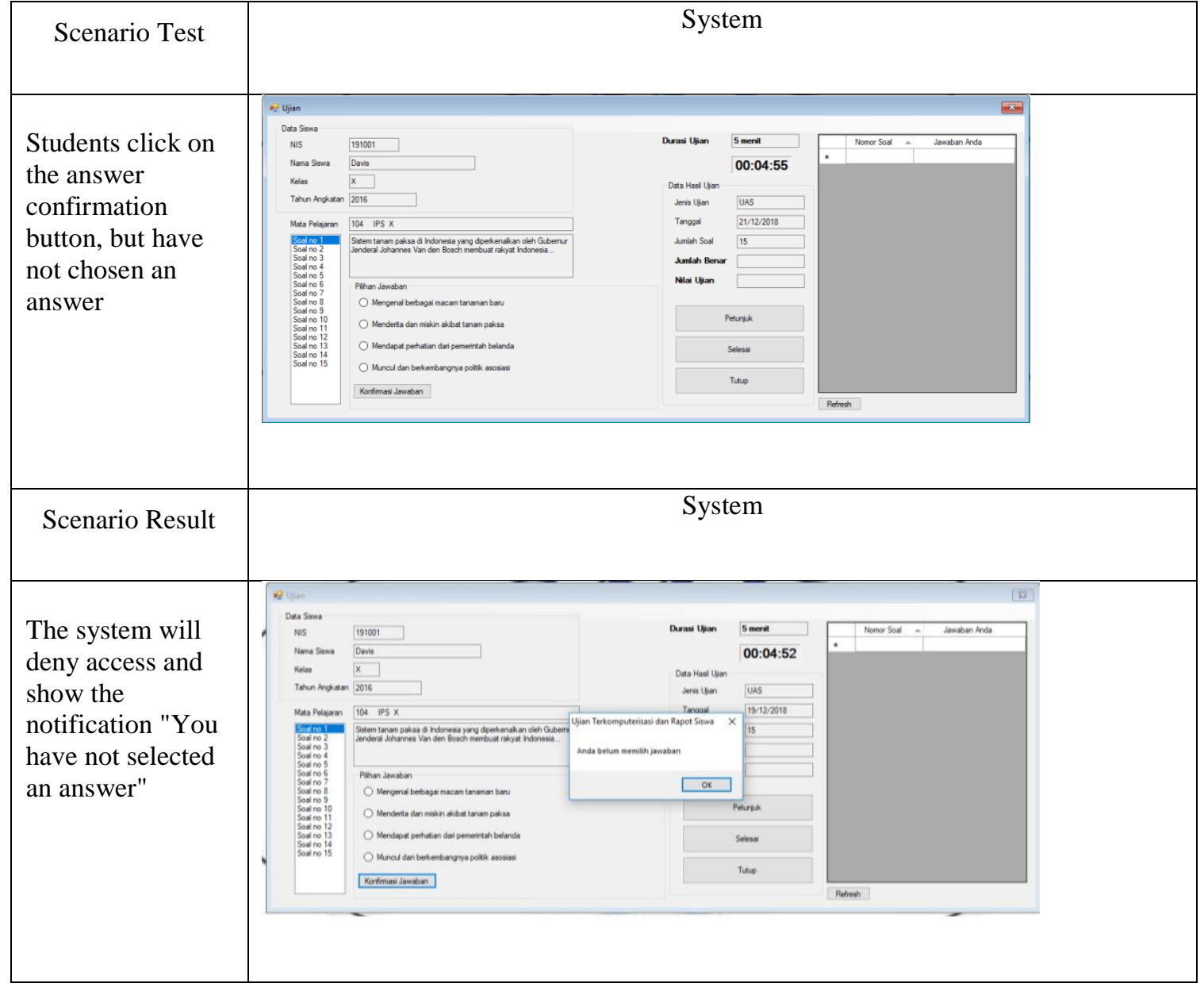

User Acceptance Test is a test carried out by the user where the user is a staff or employee of an agency that directly interacts with the system and is verified whether the existing function has been running according to its needs or functions[9].

\section{CONCLUSIONS}

Change the exam manual system become computerized, so Agathos Vocational School can save the money up to IDR 603,000 and the work time up to 8 days. The system duration feature makes students become discipline in fillingon semester exams. The system randomizes the order of semester exam questions, so that preventing cheating by students. Correction of exam answers is done automatically so the teachers becomes more effective. Student test results it's saved by electronically in database, so that it does not require a lot of space and searching of results data can be faster. The system test results of $64 \%$ can be received by the user, that is majority Agree and Strongly agree with the implemented system. 


\section{REFERENCES}

[1]. Wahana Komputer. Panduan Belajar MySQL Database Server. Jakarta Selatan : Media Kita, 2010.

[2]. Sukamto, Rosa Ariani and Shalahuddin, Muhamad. Rekayasa Perangkat Lunak Terstruktur dan Berorientasi Objek. Bandung : Informatika, 2015.

[3]. Marwan, Ady, Suttardi and Ramadhan, Rahmat. Penerapan Metode Linear Congruent Method (LCM) Dalam Perancangan Dan Pembuatan Game Monopoli Edukasi Untuk Tokoh Pahlawan Nasional. Kendari : SemanTIK, 2017. Vol. 3. 2502-8928.

[4]. Biantara, I Made Divya, et al. Modifikasi Metode Linear Congruential Generator Untuk Optimalisasi Hasil Acak. Semarang : Seminar Nasional Informatika, 2015. 1979-2328.

[5]. Futaki, Sofyan Saoqi, Marisa, Fitri and Wijaya, Indra Dharma. Aplikasi Kamus Istilah Kebudayaan Indonesia Berbasis Desktop Menggunakan Metode Fisher-Yates. Malang : JIMP - Jurnal Informatika Merdeka Pasuruan, 2018. Vol. 3. 2503-1945.

[6]. Perry, William E. Effective Methods for Software Testing. Indiana : Wiley Publishing, 2006.

[7]. Saroni, Muhammad. Orang Miskin Bukan Orang Bodoh. Yogyakarta : Bahtera Buku, 2011.

[8]. Winagun, Kuntang. Pendidikan Vokasi Sebagai Pondasi Bangsa Menghadapi Globalisasi. Ponorogo : Jurnal Taman Vokasi, 2017. Vol. 5. 2579-4159.

[9]. Zulfikar and Hubbul, Walidainy. Design and Implementations of Linear Congruential Generator into FPGA. s.1. : International Journal Of Electronics Communication and Computer Engineering, 2014. Vol. 5. 2278-4209. 